\title{
Comparison of Debris Flow Modeling Results with Empirical Formulas Applied to Russian Mountains Areas
}

\author{
Viktoriia Kurovskaia $^{1 *}$, Tatyana Vinogradova ${ }^{2}$, Anastasiia Vasiakina ${ }^{3}$ \\ ${ }^{1}$ Lomonosov Moscow State University, Leninskie Gory, Moscow, Russia \\ ${ }^{2}$ St. Petersburg State University, University Embankment, St. Petersburg, Russia \\ ${ }^{3}$ University of South-Eastern Norway, Gullbringvegen, Bø i Telemark, Norway \\ Email: *viktoriiakurovskaia@gmail.com
}

How to cite this paper: Kurovskaia, V., Vinogradova, T. and Vasiakina, A. (2020) Comparison of Debris Flow Modeling Results with Empirical Formulas Applied to Russian Mountains Areas. Open Journal of Geology, 10, 92-110.

https://doi.org/10.4236/ojg.2020.101005

Received: November 24, 2019

Accepted: January 14, 2020

Published: January 17, 2020

Copyright $\odot 2020$ by author(s) and Scientific Research Publishing Inc. This work is licensed under the Creative Commons Attribution International License (CC BY 4.0).

http://creativecommons.org/licenses/by/4.0/

\begin{abstract}
Construction of debris flow protection structures is impossible without studying the processes first. Therefore, the purpose of this research was to calculate the magnitude of debris flows in three study areas. Initial information was provided by JSC Sevkavgiprovodkhoz and the Research Center "Geodinamika". The first object of this research was the river Ardon and its tributary the Buddon, because of disastrous consequences for Mizur village of passed debris flows and floods. Modeling of unsteady water movement was carried out for estimation of potential flooding. During modeling, 5 cases of flash floods and debris flows of various probabilities from $0.5 \%$ to $1 \%$ percent were considered. Therefore, maximum floods for the cross-sections above and in the Mizur village itself were obtained. The second study area was the Chat-Bash stream, which is also situated in the north of Caucasus mountains. For this stream, the maximum discharge that could impact the mining complex at Tyrnyauz was determined. The third study area was the Krasnoselskaia river due to frequent floods in Yuzhno-Sakhalinsk. Applying three cases of various probabilities from $10 \%$ to $0.1 \%$, the model determined maximum discharge and water level for the last cross-section above confluence into the Susuya river. Numerical experiments for all study areas with different roughness values were conducted to identify optimal ones. Comparing the model results for all study areas with empirical formulas (Golubcov V.V., Herheulidze I.I., Kkhann, Sribnyj and ASFS of EMERCOM of Russia) revealed that formulas contain only average depth slope angle and empirical coefficients and do not allow estimating flood areas and maximum characteristics of the event with a certain degree of accuracy.
\end{abstract}

\section{Keywords}

Modeling, Debris Flows, Flash Floods, Maximum Discharge, Unsteady Water 


\section{Introduction}

Debris flows of various densities are frequent phenomena in north Caucasus mountains [1] and in Sakhalin region [2]. Research methods for identifying the magnitude of debris flows can be divided into calculated and experimental.

The experimental method includes observation stations, where long-term monitoring of debris flows is already taking place in many countries around the world. One of the earliest instrumental observations was held by Pierson [3] in channels on the flanks of Mount St. Helens. Recently the special equipment was applied at Chalk Cliffs in the Colorado Rocky Mountains [4] [5]. In the Alpine areas, debris flow torrent and fan monitoring is carried out by several countries: Italy, France, Switzerland and Austria [6] [7]. Also, quantitative characteristics of debris flows are measured at the Spanish station in the Pyrenees [8]. The largest debris flow observation station was opened in 1961 in China in the Jiangjai River Basin in the suburb of Donchuan, Yunnan Province [9]. Moreover, special equipment was installed in Ohya landslide, central Japan [10]. Since 2002 about 19 debris flow stations have been opened in Taiwan [11]. Additionally, the experiments on reproduction of artificial debris flows in nature, which were organized by Professor Yu. B. Vinogradov, were held in 1972-1975 in Zailiyskiy Alatau near Alma-Ata [12].

The calculation method includes the empirical formulas and mathematical modeling. Empirical formulas give only an approximate description of the debris flow movement [13], since they only take into account the flow depth and riverbed slope. Herewith, mathematical models are used, when it is necessary to obtain more accurate data about the debris flow movement and the maximum characteristics. There are many debris flow routing models, although most of them require a specific parameter, which is difficult to obtain or to calibrate. For example, RAMMS [14] [15] and FLO-2D [16] [17] can reproduce the depositional pattern of flows on alluvial fans after being calibrated using the historical data from the torrent and the fan. Since simulation models often require calibration, data from the historical events are not available for many locations, which is a major drawback for engineering applications. In addition, rheological models are used to simulate debris flows. However, they need laboratory experiments and special equipment for proper determination of the debris flow material rheology [18]. As for the input data, the accuracy of variables has significant influence on the model results. A maximum hydrograph is the boundary condition for the most hydrodynamic models. An assessment of a maximum hydrograph can be conducted on basis of the probability curve for a stream if long-term observational datasets are available. Also, a hydrograph can be calculated by taking into account the maximum volume of a lake located in the upstream reaches 
[19]. Besides, there are several models that can be applied to identify the hydrograph of outburst, further this data can be used in debris flow movement models. The hydrograph of a glacier-loaded outburst, for example, can be determined by Vinogradov Yu. B. model [20]. Moreover, in case of debris flows instrumental monitoring, infrasound array analysis can be used to define maximum characteristics [21].

The aim of this research is to calculate the maximum characteristics of the past and possible debris flows for three study areas in the mountain regions of Russia. A one-dimension Saint-Venant model was used in this paper, as it does not have a calibration requirement and the initial data that is required to run the model is quite simple. Also, the model can be applied for various geographic zones by studying mountain regions located in different areas around Russia as it was demonstrated in this paper. Additionally, we made a comparison of the model results with the values obtained from the empirical formulas.

\section{Study Areas}

The first study area was the Ardon River in North Ossetia-Alania in Russia. It flows from north and somewhat east, entering the Terek River northwest of Vladikavkaz. The length of the Ardon is about $102 \mathrm{~km}$ with the catchment area of $2700 \mathrm{~km}^{2}$ [22]. This river is formed by the merger of the Mamisondon, the Nardon, the Adaykom and the Tsmiakomdon rivers, which originate from the glaciers in the Main Caucasus mountain Range. The Buddon River is right-bank tributary of the Ardon (Figure 1). The source of the Buddon is located on northern slopes of the Caucasus mountain ridge at the foot of Tzmiakomkhoh Mountain with the maximum elevation of $4117 \mathrm{~m}$. The river length is $11 \mathrm{~km}$ with the catchment area of $42 \mathrm{~km}^{2}$ [22].

In the Buddon River basin, there are several sites within $3-4 \mathrm{~km}$ from the headwater area. Debris flows have been disastrous for Mizur village, located in the mouth of the Buddon, where schools and several buildings are situated. The flows formation begins when sediment-rich debris flows form near the headwater area of the Buddon River [23]. Once in the Ardon River (Figure 1), the debris flow became diluted and transform into floods. The modeling of these flows was conducted to protect territory in the valley of the Buddon River for Mizur village and Zaramagskaya hydroelectric station, which is under construction. Initial information, which was used for debris flow modelling, was provided by the JSC Sevkavgiprovodkhoz report of 2014 year on the Ardon River and its tributary the Buddon River.

The second study area was the Chat-Bash stream (Figure 2). It is situated in Kabardino-Balkarian Republic and enters the Kamyk-Su River, $4.6 \mathrm{~km}$ from its mouth. According to the state water register of Russia, the length of the stream is $3.3 \mathrm{~km}$ and the catchment area is estimated to be $7.6 \mathrm{~km}^{2}$. In the basin of the Chat-Bash catchment, there are three sites where landslide-initiated debris flows were recorded recently. The peak discharge of the most recent formed debris 


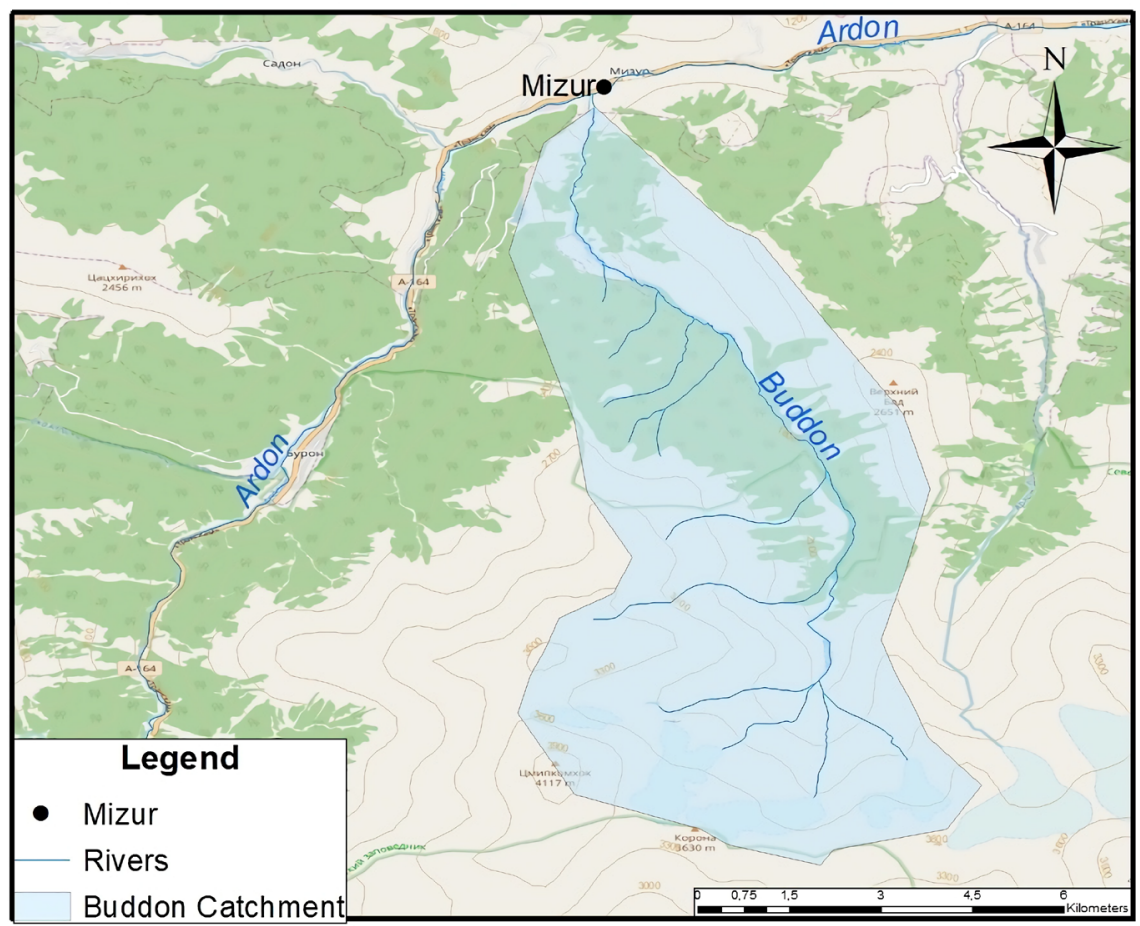

Figure 1. The Ardon River and its right-bank tributary the Buddon River.

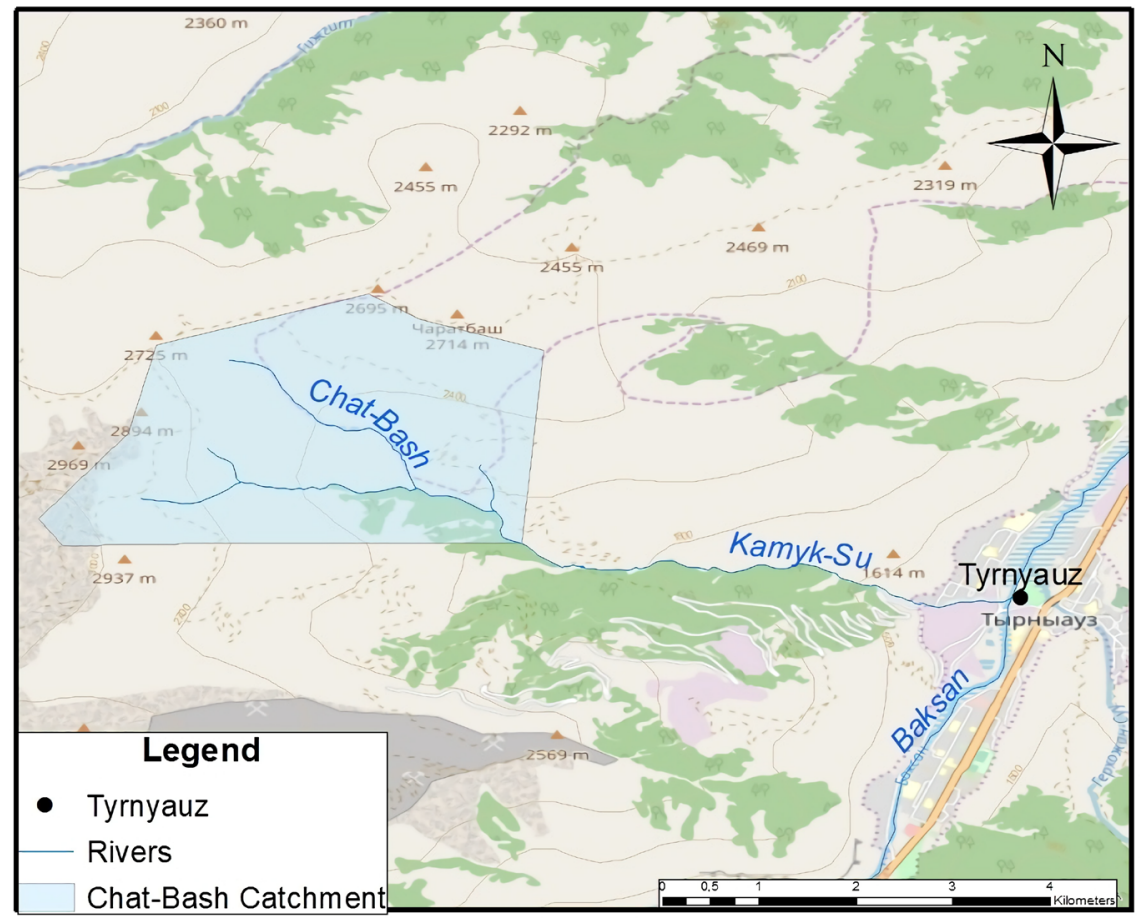

Figure 2. The Kamyk-Su River and its tributary Chat-Bash stream.

flow on June 14, 2005 was $70 \mathrm{~m}^{3} / \mathrm{s}$ [24] with a density of $1635 \mathrm{~kg} / \mathrm{m}^{3}$. Calculations were conducted at the initiative of JSC Sevkavgiprovodkhoz to protect the Tyrnyauz city. According to them, the flooding of the mining complex of Tyrnyauz will begin, when discharges in the stream reach $167 \mathrm{~m}^{3} / \mathrm{s}$. 
Our last study area was the Krasnoselskaia river (Figure 3) located in Sakhalin region. The river valley lies in the western spurs of the Susunai Range. The source is located on the northern slope of Mount Augustinovich with the absolute mark of $1034 \mathrm{~m}$, flows into the river Susuya from its left bank $36 \mathrm{~km}$ from the mouth. The Krasnoselskaia river formed at the merger of the Ligovka and the Mga rivers. The river length is $25 \mathrm{~km}$, the catchment area is $144 \mathrm{~km}^{2}$. The river flows before entering the river valley Susuya, which has mountain character. When the river exits to the Susuya river valley bottom in the area of the planning district Novo-Aleksandrovsk, the river flow acquires the features of a plain river and the basin relief is significantly changed to anthropogenic. On both sides of the river, major part of basin area has been modified by humans [25].

The floodplain is built up by private residential buildings. Before the clearing of the channel and the channel expansion, the residential sector was prone to spring flooding by the river, caused by the low capacity of the channel and the litter in it. Nevertheless, the performed hydraulic engineering measures do not allow missing the flow of rain floods with a probability of occurrence in 100 years more than $10 \%$. In that case, the residential sector will be in the flood zone [25]. Besides, bridges across the Krasnoselskaia river have an insufficient cross-section and can serve as blocks, leading to flooding of vast territories of the town. One of them (the bridge on Lenin Street) was built, most likely, without a project (Figure 4).

In 2014, riverbanks were stabilized by stone and concrete structures in washed areas, but these protective structures proved to be short-lived and ineffective and

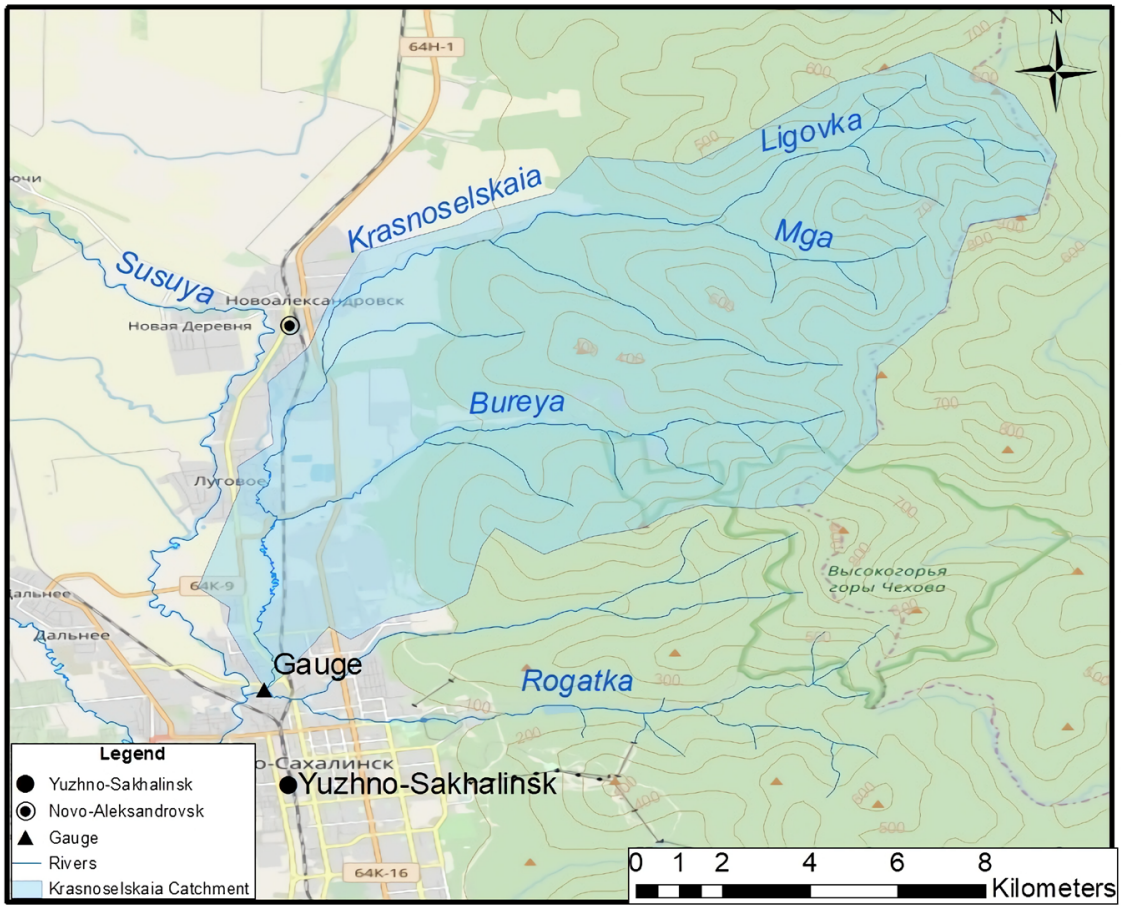

Figure 3. The Susuya River and its tributary Krasnoselskaia river. 


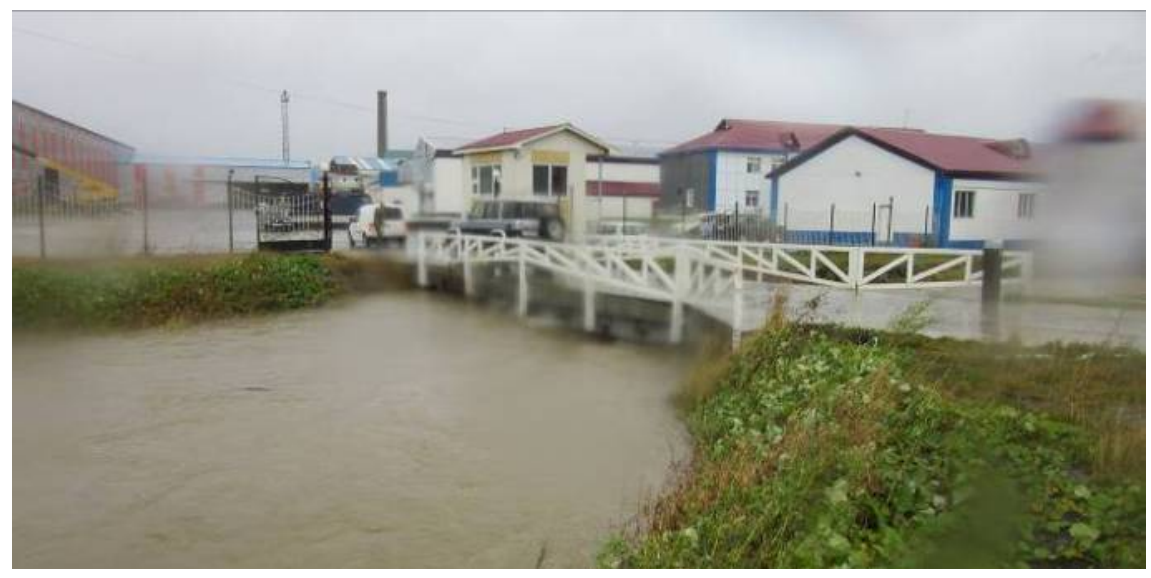

Figure 4. The bridge on Lenin Street over Krasnoselskaia river [25].

were destroyed in a single flood [25]. In August 1981, during the typhoon "Phyllis", the water discharge of the Krasnoselskaia river reached more than $173 \mathrm{~m}^{3} / \mathrm{s}$, leading to the flooding of vast territories [26]. Calculations were carried out on the initiative of the Research Center "Geodinamika" in order to compute the maximum characteristics.

\section{Methods}

A model for unsteady shallow water movement, developed by Tatyana Aleksandrovna Vinogradova at St. Petersburg State University was used to calculate the historical and possible debris flows and floods. The model is based on a one-dimensional set of Saint-Venant equations. Currently, the 1-D models are still more commonly applied than the 2-D in debris-flow research field, because of a lack of initial information for the 2-D models [27]. By applying the momentum and mass conservation laws to the mixture of a debris flow, a system of two partial differential equations is obtained, known as the Momentum equation and the Mass conservation equation. These equations can be solved using an implicit finite-difference scheme [28] [29]. A numerical scheme developed at Lavrentyev Institute of Hydrodynamics of the Siberian Branch of the RAS was applied [30]. Differential equations of the unsteady flow in open waterways in the presence of tributary inflow have the following appearance in the model:

$$
\begin{gathered}
I=i_{o}-\frac{\partial h}{\partial x}=\frac{\alpha}{g} V \frac{\partial V}{\partial x}+\frac{\beta}{g} \frac{\partial V}{\partial t}+\frac{V|V|}{C^{2} R}+\frac{q V}{g w}, \\
\frac{\partial w}{\partial t}+\frac{\partial Q}{\partial x}=q,
\end{gathered}
$$

in (1) and (2) equations, $x$ is the downstream coordinate, $t$ is the time, $h$ is the flow depth, $\mathrm{m}, V$ is the average velocity, $\mathrm{m} / \mathrm{s}, Q$ is the water-sediment discharge, $\mathrm{m}^{3} / \mathrm{s}, \omega$ is the cross-section area occupied by the flow, $\mathrm{m}^{2}, C$ is the Chezy friction factor, $g$ is the gravity acceleration, $\mathrm{m} / \mathrm{s}^{2}, R$ is area border ratio, $\mathrm{m}, \alpha$ and $\beta$ parameters depending on the shape of the cross-section and $q$ is the tributary inflow. In the first Equation (1), $i_{o}$ is the bed slope angle, $\partial h / \partial x$ is the additional 
slope, that takes into account depth change along the bed. The last term plays an important role in areas with a sharp change in the cross-section of the watercourse. The second term on the right side is the slope associated with the change in the velocity over time. It becomes essential in areas of unsteady water movement. The first and second terms on the right of the equation represent the effects of the local inertia, the third term is convective inertia.

Before the calculations, the river bed was divided into several sections. The boundary of the sections was anchored to the cross-sections, for which data of observed discharges and water levels were available. The initial data included the depth and the width of the cross-sections, duration of the hazard event, initial and maximum discharges and water levels on the cross-sections. The boundary conditions were the hydrograph for initial cross-section and change of the water level for ultimate one. Through this model, the following data for all cross-sections were obtained:

- flow hydrographs

- water level

- average flow velocity

- cross-sectional area

- width of the flow

- rate of flow

- Reynolds number (it determines the nature of the flow movement)

- Froude number (it describes kinetic energy of the flow)

Additionally, you can change the river bed coefficient of roughness in the model. Therefore, it is possible to take into account the sediment load of the stream and to model not only floods, but also low-density debris flows. Due to the fact that there are no established limits for changes in the coefficient of roughness for different flows, we conducted several numerical experiments to investigate optional one. Moreover, it is necessary to mention that this model can be applied to various geographic zones regardless of the conditions for the low density flows or floods formation.

As it was mentioned before calculation methods include not only modeling, but also empirical formulas. That is why various formulas for estimating velocity $\left(v_{c}\right)$ and discharge of debris flows were applied. The following formulas, developed by Golubcov V.V. [31], Herheulidze I.I. [31], Kkhann [32], Sribnyj [32] and Academy of the State Fire Service Emergencies Ministry of Russia (ASFS of EMERCOM of Russia) [33] are frequently used in Russia.

Golubcov V.V. proposed a calculation formula for density flows [31]:

$$
v_{c}=3.75 h^{0.5} i^{0.17},
$$

in formula (3), $h$ is the average depth of the stream, $\mathrm{m}$; $i$-slope of the mudflow bed, nondimensional.

If the debris flow does not have viscoplastic properties, then the velocity $\left(v_{c}\right)$ of the flow for a practical purpose can be calculated using the formula of Herheulidze I.I [31]: 


$$
v_{c}=4.83 h^{0.5}(\sin \alpha)^{0.25},
$$

where $h$ is the average flow depth, $\mathrm{m} ; \alpha$-average angle of slope of the mudflow bed, nondimensional.

In addition, the Kkhann formula was used to calculate debris flow velocity [32]:

$$
v_{c}=8.05 h^{0.58} i^{0.30},
$$

where $h$-the average flow depth, $\mathrm{m}$; $i$-slope of the mudflow bed, nondimensional.

Also, Sribnyj M.F. formula [32] is often used for debris flow velocity calculations:

$$
v_{c}=\frac{6.5 R^{3 / 3} i^{1 / 4}}{\sqrt{\frac{\gamma_{c} \gamma_{m}-\gamma_{m}}{\gamma_{m}-\gamma_{c}}}+1},
$$

where $R$-area border ratio, $\mathrm{m} ; i$-slope of the mudflow bed, nondimensional; $\gamma_{m}$-sediment density, $\mathrm{kg} / \mathrm{m}^{3} ; \gamma_{c}$-average debris flow density, $\mathrm{kg} / \mathrm{m}^{3}$.

Accepting the assumption that volumes of debris flow's solid and liquid components are equal, the Sribnyj M.F. formula (6) changes to:

$$
v_{c}=4.25 R^{3 / 3} i^{1 / 4}
$$

Lastly, Academy of the State Fire Service of the Ministry of Emergency Situations of Russia (ASFS of EMERCOM of Russia) have their formula [33] to determinate the velocity of debris flow movement:

$$
v_{c}=11.4 h^{0.5}\left(U \sin \alpha^{\frac{1}{3}}\right),
$$

where $U$ is the relative fall diameter of loose materials involved in the flow (for operational calculations it is assumed to be 0.7 ... 1.0).

All formulas include empirical coefficients and such characteristics as the flow depth and the riverbed slope. Some of them like formulas of Herheulidze I.I. and Golubcov V.V. were obtained during analysis of the field surveys in of the debris processes in Georgia and Kazakhstan. Another were received during laboratory experiments. Besides, in the previous research [13] the merged velocities from the video material and calculated by Kkhann formula showed similar results. However, no theoretical description is available for this formula, so it is impossible to verify the assumptions about the reliability degree of the results. In order to obtain discharges, the values of velocity from the formulas were multiplied by cross-sectional area.

\section{Calculation Results}

Modeling was conducted to clarify the hydrological and morphometric characteristics of the maximum possible floods and debris flows in the Ardon River. During calculations, 5 cases of flash floods and debris flows with probability of 
occurrence in one hundred years were considered (Table 1). These 5 cases defined maximum magnitude of debris flows and flash flood once in one hundred or even once in two hundred years. The values of these cases were obtained on basis of discharge probability curve for the Ardon and Buddon rivers [23]. The values of maximum discharges will be used for the protection territory in the valley of the Buddon River for Mizur village and Zaramagskaya hydroelectric station, which is under construction.

During the modeling, the design scheme of the Ardon River was made (Figure 5). The most important cross-sections for the modeled flow events were the $3^{\text {rd }}$ section, at the mouth of the Buddon, and $5^{\text {th }}$, directly near Mizur village. No continuous observations of discharges and water levels on the Ardon or the Buddon Rivers near Mizur village were made. Therefore, short-term data provided by JSC Sevkavgiprovodkhoz were applied. The first results showed that the Froude number was overestimated. As it was mentioned above, the Froude number describes kinetic energy, meaning that the kinetic energy of the flow was exceeded. Initial discharges and water levels were specified with data from another gauge at the Ardon River.

Table 2 shows the refined calculated values of the maximum discharges of the Ardon River on the cross-section before the confluence of the Buddon River, immediately after and opposite to Mizur village for the several cases.

The calculations show that during the flooding on the Ardon River, after the Buddon River flows into it, a rapid increase in water discharge occurs while a wave is forming.

Another task was to estimate the cross-sectional area of the modeled flow events at the $3^{\text {rd }}$ and $5^{\text {th }}$ cross-sections. Maximum value was obtained in $4^{\text {th }}$ case and was approximately $120 \mathrm{~m}^{2}$, and $116 \mathrm{~m}^{2}$ for the $5^{\text {th }}$ cross-section, while the

Table 1. 5 cases of flash floods and debris flows with probability of occurrence in one hundred years applied in the model for the Ardon and the Buddon rivers.

\begin{tabular}{cccc}
\hline № case & $\begin{array}{c}\text { R. Ardon (probability } \\
\text { of occurrence in 100 years) }\end{array}$ & $\begin{array}{c}\text { R. Baddon (probability } \\
\text { of occurrence in 100 years) }\end{array}$ & \\
\hline 1 & $0.5 \%$ & $0.5 \%$ & flash flood \\
2 & $1 \%$ & $1 \%$ & flash flood \\
3 & $10 \%$ & $10 \%$ & flash flood \\
4 & $0.5 \%$ & $0.5 \%$ & debris flow \\
5 & $1 \%$ & $1 \%$ & debris flow \\
\hline
\end{tabular}

Table 2. Maximum discharges of 5 applied cases for the $3^{\text {rd }}, 4^{\text {th }}$ and $5^{\text {th }}$ cross-sections.

\begin{tabular}{cccccc}
\hline \multirow{2}{*}{$\begin{array}{c}\text { № of } \\
\text { cross-section }\end{array}$} & Case 1 & Case 2 & Case 3 & Case 4 & Case 5 \\
\hline 3 & 183.9 & 183.9 & 183.9 & 184.0 & 184.0 \\
4 & 324.5 & 324.5 & 324.5 & 329.5 & 324.5 \\
5 & 323.9 & 324.1 & 324.1 & 329.0 & 331.0 \\
\hline
\end{tabular}




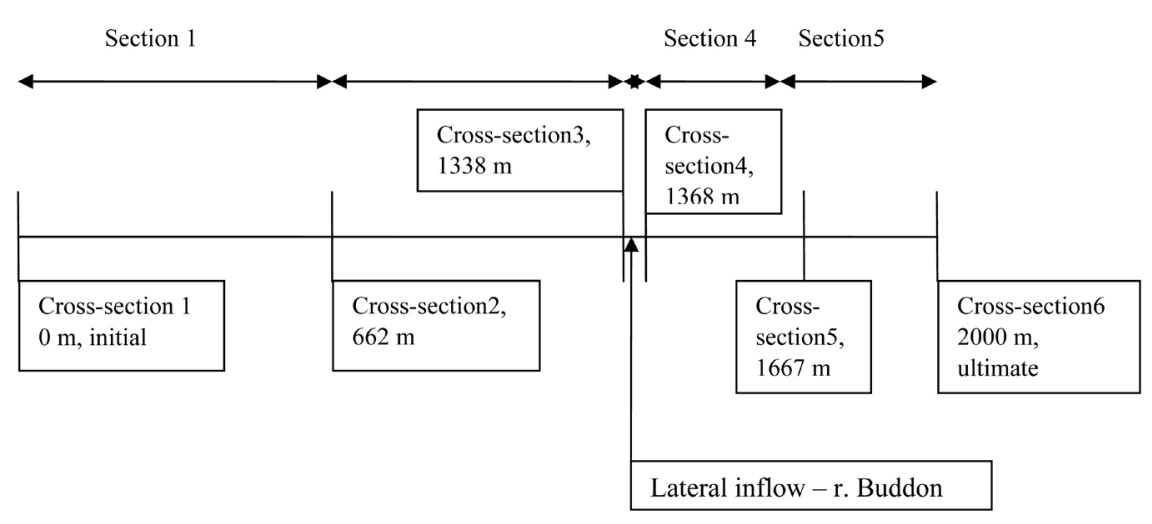

Figure 5. The designed scheme of cross-sections for the Ardon River.

flooding occurs even at a cross-sectional area of $110 \mathrm{~m}^{2}$ [34]. Besides, for cases 1 , 2 and 3, the cross-sectional area exceeds flooding area only at the $5^{\text {th }}$ cross-section. Moreover, numerical experiments were held to indicate optimal value of coefficient of roughness. In this case, optimal one was set equal to 0.08 for all cases. For the Buddon river, the calculations of debris flow velocity and discharge by different methods were conducted (Table 4). Initial information is provided in Table 3.

The formulas of Golubcov V.V. (3), Herheulidze I.I. (4), Kkhann (5), Sribnyj (6) and ASFS of EMERCOM of Russia (7) were used to compare their results with the model ones [31] [32] [33]. The smallest velocity values between empirical methods were around $5 \mathrm{~m} / \mathrm{s}$ by Herheulidze, Golubcov and Sribnyj formulas. The velocities by two other formulas (Kkhann and ASFS of EMERCOM of Russia) were twice as much-more than $8.0 \mathrm{~m} / \mathrm{s}$. Values of discharges also varied a lot among formulas, but followed the similar trend. Discharge of more than $300.0 \mathrm{~m}^{3} / \mathrm{s}$ was obtained by Kkhann and ASFS of EMERCOM of Russia. Discharges by other formulas were a third less than them. Despite such differences between formulas, model results showed the smallest values compared to empirical formulas. The maximum velocity by model was less than $1.0 \mathrm{~m} / \mathrm{s}$ and discharge was only $140.5 \mathrm{~m}^{3} / \mathrm{s}$.

The second study area was the Chat-Bash stream. The past debris flow of June 14, 2005 was calculated. Using the initial information from the report of E.V. Zaporozhchenko and A.M. Padmya [24], the scheme of the stream section was made (Figure 6). The river section was divided into two parts, morphometry and hydrological data were anchored to the cross-sections.

$185 \mathrm{~m}^{3} / \mathrm{s}$ is the maximum discharge which was obtained for the Chat-Bash stream by the model, while the flooding of the dumps at the mining complex of Tyrnyauz began at $167 \mathrm{~m}^{3} / \mathrm{s}$ (Figure 7 ).

On the top of that, we conducted the modeling of debris flow with the change in roughness to determine the optimal one. In these calculations, coefficient of roughness value was determined as 0.075 .

The highest velocity $(4.20 \mathrm{~m} / \mathrm{s})$ was obtained with a roughness of 0.085 , while the maximum flow discharge $\left(185.9 \mathrm{~m}^{3} / \mathrm{s}\right)$ with $n=0.09$. Thus, the flooding of 
Table 3. Initial information for the Buddon river using the data of 2014 year.

\begin{tabular}{cccc}
\hline № of cross-section & Depth, $\mathrm{m}$ & Slope, $^{\circ}$ & Hydraulic size, $\mathrm{m} / \mathrm{s}$ \\
\hline 1 & 2.66 & 0.087 & 0.70 \\
2 & 2.96 & 0.087 & 0.70 \\
3 & 3.74 & 0.087 & 0.70 \\
mean & 3.12 & 0.090 & 0.70 \\
\hline
\end{tabular}

Section 1

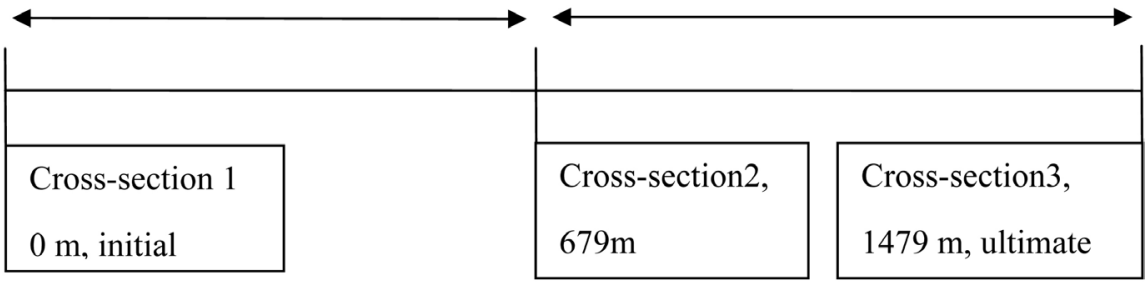

Figure 6. The designed scheme of cross-sections for the Chat-Bash stream.

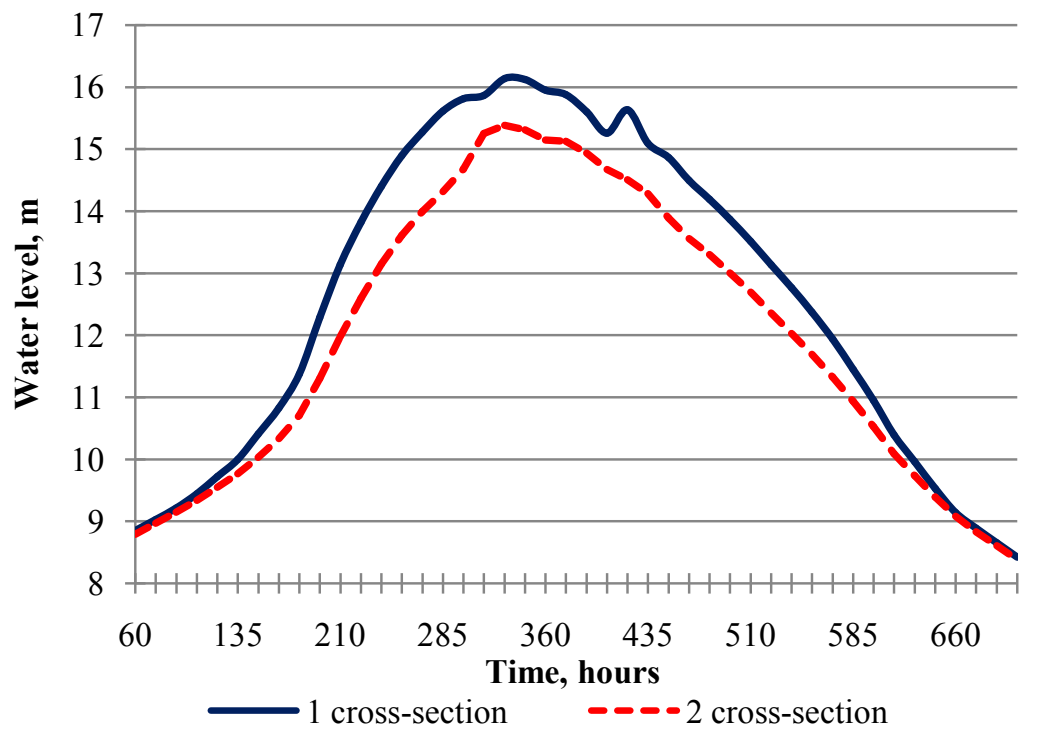

Figure 7. Combined graph of water level changes on two cross-sections for the Chat-Bash stream.

the dumps of the mining complex of Tyrnyauz begins at any value of the roughness coefficient.

Furthermore, the results of modeling (Table 4) were compared with formulas of Golubcov V.V. (3), Herheulidze I.I. (4), Kkhann (5), Sribnyj (6) and ASFS of EMERCOM of Russia (7) [31] [32] [33]. The initial information for the formulas can be found in Table 5 .

The results of calculations are presented in Table 6. As already mentioned, the results obtained using these formulas differed significantly. The smallest values of maximum debris flow velocity around $4.0 \mathrm{~m} / \mathrm{s}$ were by the same formulas as for the Buddon (Herheulidze, Sribnyj and Golubcov formulas). The highest 
Table 4. Maximum velocity and discharge of debris flow calculated according to different methods for the Buddon river using data of 2014 year.

\begin{tabular}{ccc}
\hline Methods & Velocity, $v_{c}(\mathrm{~m} / \mathrm{s})$ & Discharge $\left(\mathrm{m}^{3} / \mathrm{s}\right)$ \\
\hline by Herheulidze I. I. & 5.1 & 197.3 \\
by Golubcov V. V. & 4.8 & 186.3 \\
by Kkhann & 8.3 & 323.5 \\
by ASFS of EMERCOM of Russia & 8.7 & 337.4 \\
by Sribnyj M. F. & 5.6 & 216.3 \\
by the model of unsteady water movement & 0.8 & 140.5 \\
\hline
\end{tabular}

Table 5. Initial information for the Chat-Bash stream.

\begin{tabular}{cccc}
\hline № of cross-section & Depth, $\mathrm{m}$ & Slope, & Hydraulic size, $\mathrm{m} / \mathrm{s}$ \\
\hline 1 & 2.44 & 0.15 & 0.85 \\
2 & 2.48 & 0.15 & 0.85 \\
3 & 1.59 & 0.15 & 0.85 \\
mean & 2.17 & 0.15 & 0.85 \\
\hline
\end{tabular}

Table 6. Maximum velocity and discharge of debris flow, calculated according to different methods for the Chat-Bash stream.

\begin{tabular}{ccc}
\hline Methods & Velocity, $v_{c}(\mathrm{~m} / \mathrm{s})$ & Discharge $\left(\mathrm{m}^{3} / \mathrm{s}\right)$ \\
\hline by Herheulidze I.I. & 4.7 & 116.0 \\
by Golubcov V.V. & 4.3 & 104.8 \\
by Kkhann & 7.7 & 189.0 \\
by ASFS of EMERCOM of Russia & 9.0 & 221.4 \\
by Sribnyj M.F. & 4.8 & 118.7 \\
by the model of unsteady water movement & 4.1 & 185.0 \\
\hline
\end{tabular}

velocity value of $9.0 \mathrm{~m} / \mathrm{s}$ was calculated by using ASFS of EMERCOM of Russia formula. Debris flow discharges also varied a lot. As well as for velocities, the highest discharge of more than $200 \mathrm{~m}^{3} / \mathrm{s}$ was by the ASFS of EMERCOM of Russia formula. Discharge value was half as much $-100 \mathrm{~m}^{3} / \mathrm{s}$, according to the Golubcov formula. The model showed the similar results for velocity value as Herheulidze, Sribnyj and Golubcov formulas-4.1 m/s. However, model discharges values were closer to the results of two other formulas- $185.0 \mathrm{~m}^{3} / \mathrm{s}$.

As mentioned earlier, a significant part of the Krasnoselskaia river catchment is located in the urban area of Yuzhno-Sakhalinsk city. Due to the frequent flooding of the city territory, a calculation was made to determine the characteristics of flash floods and low-density debris flows for the Krasnoselskaia river. Initial information about the channel morphometry, as well as cases for setting the maximum discharges and various probabilities of occurrence in 100 years were provided by the employees of the Research Center "Geodinamika". The 
calculation of the maximum discharges (Table 7) for study river was carried out according to the ultimate flow rate formula [25].

During the data preparation, the designed scheme of the river cross-sections in the city was made (Figure 8). The calculation was conducted for the section of the river near the mouth. The river section was divided into 2 parts according to changes in morphometry and presence of hydrological data. The calculation duration was 96 hours, taking into account the typhoon "Phyllis" that passed in 1981, which lasted from August 5 to 8 with the maximum discharge of $173 \mathrm{~m}^{3} / \mathrm{s}$ [26].

As a result, we obtained hydrological and morphometric characteristics for all cross-sections. Due to the fact that the model boundary conditions were the flood hydrograph for the $1^{\text {st }}$ cross-section and water level fluctuation at the closing cross-section, particular interest was the transformation of discharge at the $3^{\text {rd }}$ cross-section and the water level at the $1^{\text {st }}$ cross-section respectively. The $1^{\text {st }}$ cross-section is located no more than 200 meters above the confluence of the Krasnoselskaia river in Susuya. The figure below shows the hydrographs of the flood of various probabilities of occurrence in 100 years at the $3^{\text {rd }}$ cross-section (Figure 9).

As it can be seen, the maximum discharge is $249.8 \mathrm{~m}^{3} / \mathrm{s}$, the minimum discharge is $84.7 \mathrm{~m}^{3} / \mathrm{s}$. Discharge peak was observed from 52 to 53 hours. As for the water level fluctuation over time, Figure 10 shows the level values for $1^{\text {st }}$ cross-section for the three cases for probability of occurrence in 100 years. The maximum water level was $33.5 \mathrm{~m}$ (with a probability of occurrence in 100 of $0.1 \%)$, the minimum was $32.2(10 \%)$ with an initial $29.6 \mathrm{~m}$.

Territory flooding in the last cross-section occurs at a depth of 3.7 to 3.3 meters for $1^{\text {st }}$ and $3^{\text {rd }}$ calculation cases. At the second cross-section, during the wave peak, the depth varies from 1.6 to 2.0 meters. Numerical experiments were carried out to clarify the optimal roughness coefficient, which was 0.075 .

Table 7. Adopted cases for calculating various probabilities of occurrence in 100 years for the Krasnoselskaia river.

\begin{tabular}{ccc}
\hline № case & $\begin{array}{c}\text { R. Krasnoselskaia } \\
\text { (probability of occurrence in } 100 \text { years) }\end{array}$ & Maximum water discharge $\left(\mathrm{Q}, \mathrm{m}^{3} / \mathrm{s}\right)$ \\
\hline 1 & $10 \%$ & 82.7 \\
2 & $1 \%$ & 168.1 \\
3 & $0.1 \%$ & 252.9 \\
\hline
\end{tabular}

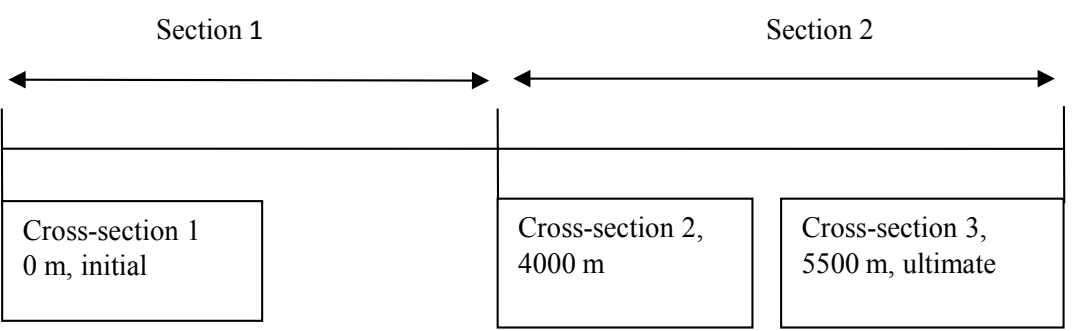

Figure 8. The designed scheme of cross-sections for the Krasnoselskaia river. 


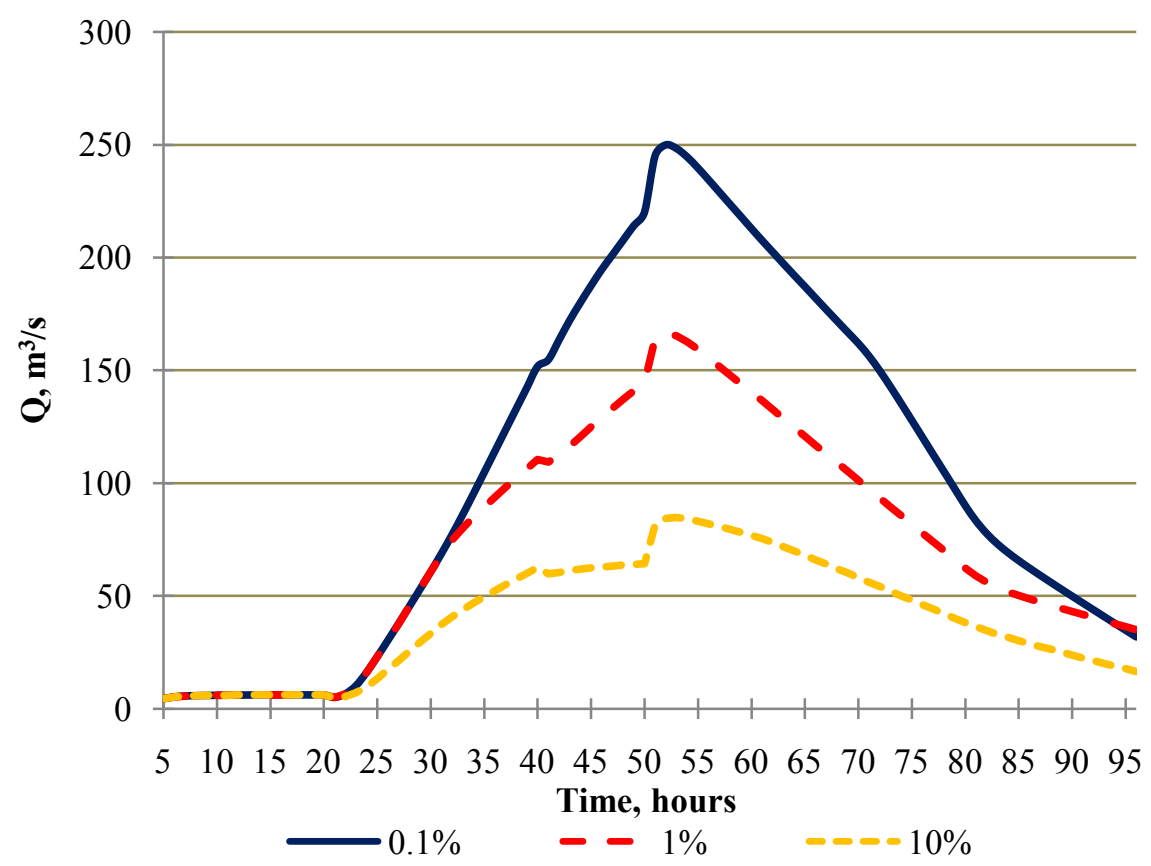

Figure 9. Calculated hydrograph of different probability of occurrence in 100 years for the $3^{\text {rd }}$ cross-section of the Krasnoselskaia river.

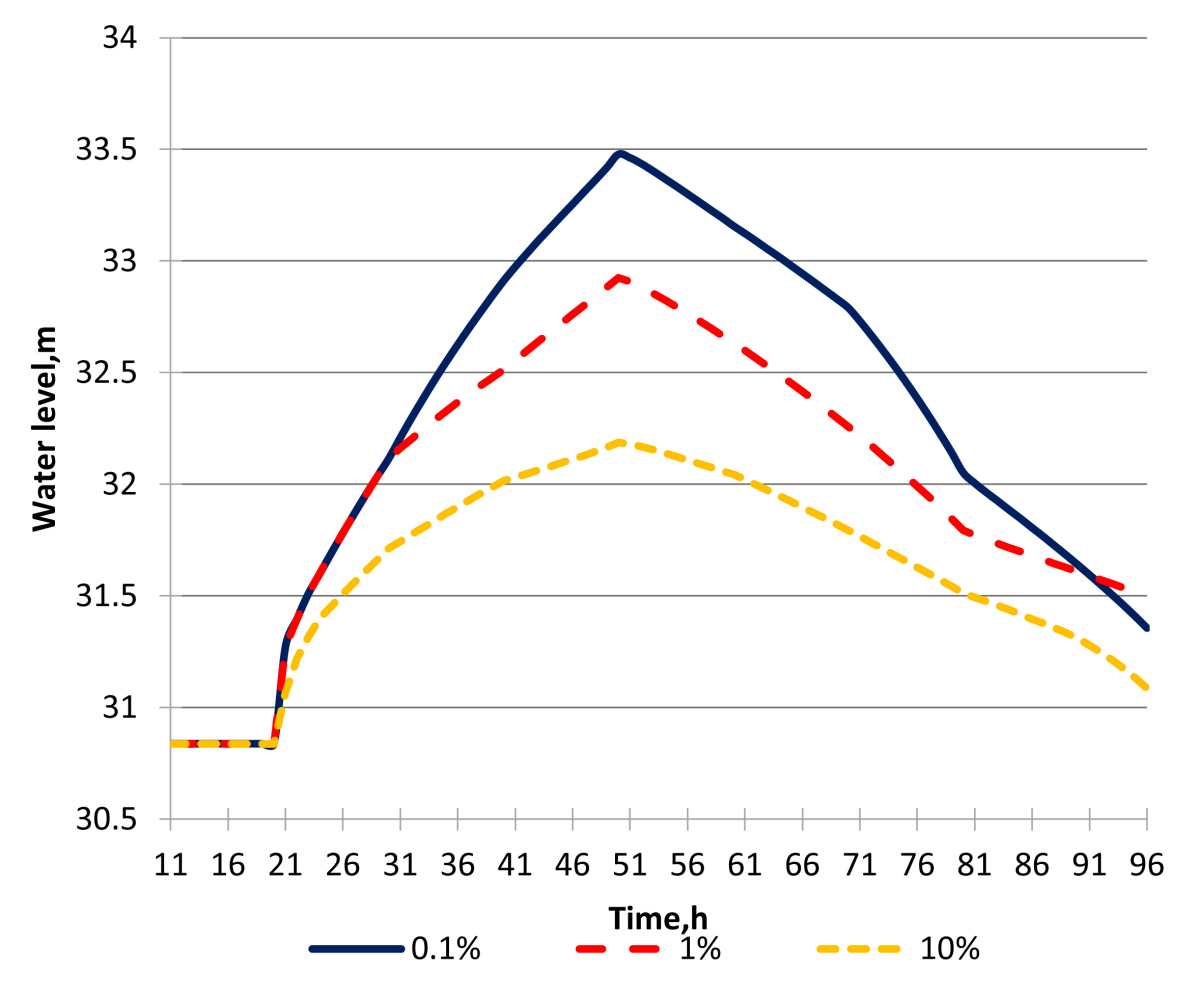

Figure 10. Calculated water-level of different probability of occurrence in 100 years for the $3^{\text {rd }}$ cross-section of the Krasnoselskaia river.

Additionally, calculations of the maximum velocity values and debris flow discharges according to the empirical formulas listed above for all three cross-sections were carried out. Initial information for the Krasnoselskaia river 
calculations is provided in Table 8.

When comparing the model results with the formulas, a probability of occurrence in 100 years of $10 \%$ was used, due to the greater likelihood of occurrence (Table 9). The highest velocities (about $13-15 \mathrm{~m} / \mathrm{s}$ ) and discharges (300 - 360 $\mathrm{m}^{3} / \mathrm{s}$ ) were obtained by two empirical formulas-by Kkhann and by ASFS of EMERCOM of Russia. Calculated values by the other methods for both velocities and discharges were two times smaller. The results calculated by the model had the smallest values for both velocity (less than $1 \mathrm{~m} / \mathrm{s}$ ) and discharge (less than 90 $\mathrm{m}^{3} / \mathrm{s}$ ) in comparison with empirical formulas used in this research.

The low velocities obtained by the model of unstable water movement are caused by the following: wave velocity begins to decrease if the absence of backwater occurs and the wave spreads out over nearby areas. The total width for the Krasnoselskaia river cross-section on average is $300 \mathrm{~m}$, thus during the passage of the wave, spreading along the floodplain occurs. However, the formulas use only such characteristics of the channel itself as the depth and the slope, thus it is impossible to say whether an overflow will be observed or not. This model is one-dimensional, so it is possible to determine the velocity values only for the entire cross-section without specifying on the channel and the floodplain. Despite lower model values, flooding of urban infrastructure structures is observed.

\section{Conclusions}

In this research low-density debris flows and flash floods were modeled on the Ardon River. Initial information for modeling was provided by JSC Sevkavgiprovodkhoz. One of the tasks was to estimate the maximum cross-sectional area for 2 cross-sections near the Mizur village. The maximum discharges were also

Table 8. Initial information for the Krasnoselskaia river.

\begin{tabular}{cccc}
\hline № of cross-section & Depth, $\mathrm{m}$ & Slope, & Hydraulic size, $\mathrm{m} / \mathrm{s}$ \\
\hline 1 & 2.44 & 0.58 & 0.85 \\
2 & 2.78 & 0.58 & 0.85 \\
3 & 3.06 & 0.58 & 0.85 \\
mean & 2.76 & 0.58 & 0.85
\end{tabular}

Table 9. Maximum velocity and discharge of debris flow, calculated according to different methods for the Krasnoselskaia river.

\begin{tabular}{ccc}
\hline Methods & Velocity, $v_{c}(\mathrm{~m} / \mathrm{s})$ & Discharge $\left(\mathrm{m}^{3} / \mathrm{s}\right)$ \\
\hline by Herheulidze I.I. & 7.4 & 170.1 \\
by Golubcov V.V. & 6.0 & 137.9 \\
by Kkhann & 13.1 & 299.4 \\
by ASFS of EMERCOM of Russia & 15.8 & 363.4 \\
by Sribnyj M.F. & 7.8 & 177.5 \\
by the model of unsteady water movement & 0.3 & 84.7 \\
\hline
\end{tabular}


calculated. This information is particularly important for the territory protection in the valley of the Buddon River for Zaramagskaya HPP-1, which is under construction. 5 cases of probability of debris flows and flash floods occurrence in 100 years were applied. Additionally, numerical experiments were conducted to identify optimal coefficient of roughness, which was equal to 0.08. Empirical formulas of Golubcov V.V., Herheulidze I.I., Kkhann, Sribnyj and the Academy of the State Fire Service Emergencies Ministry of Russia were used to estimate debris flow velocity and discharges for the Buddon river. As it was listed above, these formulas provide approximate definition of debris flows characteristics, because the model does not include the dynamics of the flow.

On the Chat-Bash stream, the calculations were carried out on the initiative of JSC Sevkavgiprovodkhoz to protect the Tyrnyauz city. The flooding of the dumps of the mining complex began at flow discharge of $167 \mathrm{~m}^{3} / \mathrm{s}$. According to the first calculations, maximum discharge of the debris flow was $175.8 \mathrm{~m}^{3} / \mathrm{s}$. Then experiments were carried out to determine optimal coefficient of roughness and it was found to be 0.075 . We also compared the results of modeling with empirical formulas mentioned above. Even though the model of unsteady water movement does not take into account the size and composition of the loss material and the debris flow density, it is a linked system and gives plausible results. For more correct and reasonable calculations, it is necessary to obtain more accurate initial data.

As for the Krasnoselskaia river, maximum hydrological and morphometric characteristics of possible floods and low-density debris flows were obtained. Three cases of various probabilities in 100 years were considered. The study revealed transformation of waveform during hazardous events. The most important hydrographs were for the $3^{\text {rd }}$ cross-section, which is located no more than 200 meters above the confluence of the Krasnoselskaia into the Susuya river in the city limits of Yuzhno-Sakhalinsk. The maximum derived discharge was 249.8 $\mathrm{m}^{3} / \mathrm{s}$ and the lowest $-84.7 \mathrm{~m}^{3} / \mathrm{s}$. Also several numerical experiments with defining coefficient of roughness were conducted, it was determined as 0.075 . The comparison of modelled results with empirical formulas indicated the inability of empirical formulas to account for the overflow. Despite the fact that the model of unsteady movement is a one-dimensional model and is able to determine values only for a specific cross-section, it allows estimating flood areas and maximum characteristics of the event.

\section{Conflicts of Interest}

The authors declare no conflicts of interest regarding the publication of this paper.

\section{References}

[1] Malneva, I.V. and Kononova, N.K. (2012) Mudflow Activity in the Territory of Russia and Neighboring Countries in the 21 Century. GeoRisk, 4, 48-54. 
[2] Kazakov, N.A. and Gensiorovskiy, Y.V. (2008) Debris Flows of Catastrophic Volumes in the Lowlands of Sakhalin Island. Proceedings of International Conference on, Mudflows. Disasters, Risk, Forecast, Protection, Pyatigorsk, 45-48.

[3] Pierson, T.C. (1986) Flow Behavior of Channelized Debris Flows, Mount St. Helens, Washington, in: Hillslope Processes, the Binghamton Symp. Geomorphology, 269-296. https://www.researchgate.net/publication/284479014

[4] Coe, J.A., Kinner, D.A. and Godt, J.W. (2008) Initiation Conditions for Debris Flows Generated by Runoff at Chalk Cliffs, Central Colorado. Geomorphology, 96, 270-297. https://doi.org/10.1016/j.geomorph.2007.03.017

[5] McCoy, S.W., Kean, J.W., Coe, J.A., Staley, D.M., Wasklewicz, T.A. and Tucker, G.E. (2010) Evolution of a Natural Debris Flow: In Situ Measurements of Flow Dynamics, Video Imagery, and Terrestrial Laser Scanning. Geology, 38, 735-738.

https://doi.org/10.1130/G30928.1

[6] Comiti, F., Marchi, L., Macconi, P., Arattano, M., Bertoldi, G., Borga, M., Brardinoni, F., Cavalli, M., D’Agostino, V., Penna, D. and Theule, J. (2014) A New Monitoring Station for Debris Flows in the European Alps: First Observations in the Gadria Basin. Natural Hazards, 73, 1175-1198. https://doi.org/10.1007/s11069-014-1088-5

[7] Pasculli, A., Cinosi, J., Turconi, L. and Sciarra, N. (2019) Parametric Study of an Alpine Wet Debris Flow Event (Novalesa, Torino, Italy) Applying The Finite Volume Method (FVM), Comparison with Available Experimental Data. IOP Conference Series: Earth and Environmental Science, 221, Article ID: 012160. https://doi.org/10.1088/1755-1315/221/1/012160

[8] Hürlimann, M., Abancó, C., Moya, J., Berenguer, M. and Vilajosana, I. (2016) Debris-Flow Monitoring for the Set-up of a Warning and Alarm System-Experiences from the Pyrenees-. International Journal of Erosion Control Engineering, 9, 107-113. https://doi.org/10.13101/ijece.9.107

[9] Hu, K.H., Hu, C., Li, Y. and Peng, C. (2011) Characteristics and Mechanism of Debris-Flow Surges at Jiangjia Ravine. Proceedings of 2011 International Conference on Debris-Flow Hazards Mitigation: Mechanics, Prediction, and Assessment, 211-217.

[10] Imaizumi, F., Masui, T., Yokota, Y., Tsunetaka, H., Hayakawa, Y.S. and Hotta, N. (2019) Initiation and Runout Characteristics of Debris Flow Surges in Ohya Landslide Scar, Japan. Geomorphology, 339, 58-69.

https://doi.org/10.1016/j.geomorph.2019.04.026

[11] Huanga, Y.M., Fang, Y.M. and Yin, H.Y. (2019) The Vibrational Characteristics of Debris Flow in Taiwan. Proceedings of 7 th International Conference on Debris-Flow Hazards Mitigation, Golden, CO, 10-13 June 2019, 1-8.

[12] Vinogradova, T.A. and Vinogradov, A.Y. (2017) The Experimental Debris Flows in the Chemolgan River Basin. Natural Hazards, 88, 189-198.

https://doi.org/10.1007/s11069-017-2853-Z

[13] Kurovskaia, V., Sokolova, D., Ostashov, A. and Vinogradova, T. (2019) Comparison of Debris Flow Characteristics Obtained by Using Video Materials and Modeling. Open Journal of Geology, 9, 75-88. https://doi.org/10.4236/ojg.2019.92007

[14] Bezak, N., Sodnik, J. and Mikoš, M. (2019) Impact of a Random Sequence of Debris Flows on Torrential Fan Formation. Geosciences, 9, 64. https://doi.org/10.3390/geosciences 9020064

[15] Dietrich, A. and Krautblatter, M. (2019) Deciphering Controls for Debris-Flow Erosion Derived from a LiDAR-Recorded Extreme Event and a Calibrated Numerical Model (Roßbichelbach, Germany). Earth Surface Processes and Landforms, 44, 
1346-1361. https://doi.org/10.1002/esp.4578

[16] O’Brien, J.S., Julien, P.Y. and Fullerton, W.T. (1993) Two-Dimensional Water Flood and Mudflow Simulation. Journal of Hydraulic Engineering, 119, 244-261. https://doi.org/10.1061/(ASCE)0733-9429(1993)119:2(244)

[17] Petrakov, D.A., Tutubalina, O.V., Aleinikov, A.A., Chernomorets, S.S., Evans, S.G., Kidyaeva, V.M., Krylenko, I.N., Norin, S.V., Shakhmina, M.S. and Seynova, I.B. (2012) Monitoring of Bashkara Glacier Lakes (Central Caucasus, Russia) and Modelling of their Potential Outburst. Natural Hazards, 61, 1293-1316. https://doi.org/10.1007/s11069-011-9983-5

[18] Liu, K.-F. and Huang, M.-C. (2006) Numerical Simulation of Debris Flow with Application on Hazard Area Mapping. Computational Geosciences, 10, 221-240. https://doi.org/10.1007/s10596-005-9020-4

[19] Kidiaeva, V.M., Petrakov, D.A., Krylenko, I.N., Aleynikov, A.A., Shtoffel, M. and Graf, K. (2018) Experience of Modeling the Breakthrough of Bashkara Lakes. GeoRisk, 12, 38-46.

[20] Vinogradov, Y.B. (1977) Glacial Outburst Floods and Debris Flows. Gidrometeoizdat, Leningrad, 155.

[21] Marchetti, E., Walter, F., Barfucci, G., Genco, R., Wenner, M., Ripepe, M., McArdell, B. and Price, C. (2019) Infrasound Array Analysis of Debris Flow Activity and Implication for Early Warning. Journal of Geophysical Research: Earth Surface, 124, 567-587. https://doi.org/10.1029/2018JF004785

[22] Surface Water Resources of USSR: Hydrologic Coverage (1964) The North Caucasus. Gidrometeoizdat, 8, 309.

[23] Skpirnyuk, O.V. and Nikulin, A.S. (2012) Engineering and Hydrological Surveys on the River Buddon and Modeling of Water-Rock Flows on the Conjugation of the Buddon-Ardon Rivers for the Development of Working Documentation for the Object: Protection of the Territory in the Valley of the River Buddon (Zaramagskaya HPP1). 88.

[24] Zaporozhchenko, E.V. and Padmya, A.M. (2005) Protection of the Tyrnyauz City of the CBD from Flooding of the r. Baksan in the Mudslide r. Kamyk-Su. 90.

[25] Report on Scientific Research (2015) Assessment of the Possibility of the Manifestation of Secondary Phenomena from Earthquakes and Their Spatial Localization in the Sakhalin Region: The Danger of Channel Processes and Floods in the City of Yuzhno-Sakhalinsk, Sakhalin Region. FEGI FEB RAS, Yuzhno-Sakhalinsk, 30-63.

[26] State Water Cadastre (1981) Annual Data on the Regime and Resources of Surface Land Water. Sakhalin Island and Kuril Islands River Basins, Gidrometeoizdat, Leningrad, 1.

[27] Arattano, M., Franzi, L. and Marchi, L. (2006) Influence of Rheology on Debris-Flow Simulation. Natural Hazards and Earth System Science, 6, 519-528. https://doi.org/10.5194/nhess-6-519-2006

[28] Cunge, J.A., Holly Jr., F.M. and Verwey, A. (1980) Practical Aspects of Computational River Hydraulics. Pitman, London, 3. https://www.researchgate.net/publication/247219193

[29] Hoskin, N.E. and Abbott, M.B. (1968) An Introduction to the Method of Characteristics. The Mathematical Gazette, 52, 207-208. https://doi.org/10.2307/3612750

[30] Vinogradova, T.A. and Nikiforovskaya, V.S. (2015) On Mathematical Modeling of the Formation of Heat and Mass Transfer Processes in River and Lake-River Systems. Proceedings of the Fourth All-Union Scientific Conference on Fundamental 
Problems of Water and Water Resources, Moscow, 102-106.

[31] RD 52.30.238-90 (1990) Guide to Debris Flow Stations and Hydrographic Batches. Organization and Conduct of Research on Debris Flow, Gidrometeoizdat, Moscow, 1.

[32] Golubcov, V.V. (1969) About the Hydraulic Resistance and a Formula for Calculation of Average Speed of a Current of the Mountain Rivers. Questions of Studying of Mudflows, Works, 33, 30-43.

[33] Kryukov, E.V. and Butenko, V.M. (2013) Dangerous Natural Processes: Manual. Academy of the State Fire Service of the Ministry of Emergency Situations of Russia, 119.

[34] Vinogradova, T.A. and Kurovskaia, V.A. (2017) Calculations of Transports and Shift Formation Processes of Mudflows. Questions of Geography and Geoecology, 3, 69-78. 